\title{
Symposium De toekomst van de informele zorg
}

Marjolein Broese van Groenou, Alice de Boer, Kim Putters, Kene Henkens, Henk Nies en Pearl Dykstra

Correspondentieadres: prof.dr. M. Broese van Groenou, afdeling Sociologie, FSW, Vrije Universiteit, De Boelelaan 1081, 1081 HV Amsterdam, m.i.broesevangroenou@vu.nl

Verschenen in 2017 in Tijdschrift voor Gerontologie en Geriatrie, 48.

\section{Samenvatting}

Sinds de hervorming van de langdurige zorg in 2015 is de vraag of kwetsbare burgers de zorg krijgen die ze nodig hebben. Mensen die hulp nodig hebben doen in toenemende mate een beroep op hun directe sociale omgeving. Dat beroep op de informele zorg vraagt veel veerkracht en organisatievermogen van families, maar ook van vrijwilligers, professionals en werkgevers. Wat betekent dit voor de toekomstige invulling en vormgeving van de informele zorg? Het symposium 'Toekomst van de informele zorg', georganiseerd op 26 januari 2017 door het Sociaal en Cultureel Planbureau en het Institute for Societal Resilience van de VU, was gewijd aan mogelijke antwoorden op deze vraag. In haar oratie ging Alice de Boer in op ongelijkheid als mogelijke determinant en uitkomst van informele zorg. Enkele conclusies uit de bijdragen:

- Tot 2050 verdubbelt het aantal 75 plussers tot ongeveer 3 miljoen personen maar neemt het aantal informele helpers af. Naast het hebben van sociale en economische hulpbronnen ('de have \& have nots') zijn capaciteiten om zorg te organiseren ('de can \& can-not's) van toenemend belang.

- Bijna de helft van de werkende ouderen biedt kort voor hun pensioen mantelzorg. Flexibiliteit op de werkplek kan mensen helpen werk en mantelzorg makkelijker te combineren, maar ongeveer de helft van de werkenden geeft aan dat thuiswerken en deeltijdpensioen niet mogelijk is.

- Mantelzorgers en zorgprofessionals verlenen hulp vanuit een perspectief en identiteit die meer overlappend dan onderscheidend zijn. Benadrukken van wat men deelt in de zorgverlening verbetert de kans op samenwerking.

- Tussen 2002 en 2014 nam het aandeel volwassen kinderen dat huishoudelijke hulp verleent aan hun ouders gestaag toe. Dit suggereert een toenemende solidariteit binnen families, maar huidig beleid kan leiden tot meer genderongelijkheid binnen families.

- Partners en kinderen blijven ook in de toekomst de belangrijkste mantelzorgers, bij voorkeur met ondersteuning van verschillende typen hulpverleners. Het organiseren en regisseren van een groot zorgnetwerk vereist wel capaciteiten die niet iedereen bezit. 
- Het geven van informele hulp vergroot het risico op overbelasting en verzuim op werk of opleiding. Kwetsbare groepen mantelzorgers zijn, ook in de toekomst, vrouwen, partners, migranten en jonge mantelzorgers.

Trefwoorden: informele zorg, arbeid, families, beleid, ongelijkheid 


\section{Symposium The future of informal care}

Marjolein Broese van Groenou, Alice de Boer, Kim Putters, Kene Henkens, Henk Nies en Pearl Dykstra

Address correspondence to: M. Broese van Groenou, PhD, dept. Of Sociology, FSS, Vrije Universiteit, De Boelelaan 1081, 1081 HV Amsterdam, the Netherlands, m.i.broesevangroenou@vu.nl

\section{Summary}

Due to the reform of long term care in 2015, there is growing concern about whether groups at risk receive the care they need. People in need of care have to rely more on help from their social network. The increased need for informal care requires resilience and organizational skills of families, but also of volunteers, professionals and employers. What does this mean for the provision of informal care in the next decennia? The symposium 'The future of informal care', organized on January 262017 by the National Institute for Social Research and the Institute for Societal Resilience of the Vrije Universiteit, addressed possible answers to this question. In her inaugural speech Alice de Boer discussed social inequality as possible determinant and outcome of informal care. Some conclusions:

- Untill 2050 the absolute number of 75-plus doubled to about 3 million persons, but the number of informal caregivers will decrease. In addition to the importance of social and economic resources (the 'have $\&$ have nots'), the ability to arrange care (the 'can \& can nots') gains importance.

- Almost half of the older employers provides informal care just before retirement. Flexibility in working hours and work location facilitates combining work and care, but about half of the employers indicates that partial retirement and working at home are no options.

- Informal caregivers and professionals often provide care from comparable perspectives and identities. Addressing similarities rather than differences improves their chances for collaboration.

- The number of adult children provide household care to older parents increased between 2002 and 2014. This suggests an increase in family solidarity, but current reform policies may increase the gender inequality in caregiving families.

- Spouses and children remain primary caregivers in the future, preferably supported by many different types of caregivers. Not everybody has the capabilities to organize and direct suchy a large care network. 
- Providing informal care increases the risk for overburden and absence at work or education. Informal caregivers at risk remain, also in the future, women, spouses, migrants, and younger carers.

Key words: informal care, employment, family, policy, inequality 
Hoe gaat de participatiesamenleving in de toekomst zorgen voor de groeiende groep ouderen?

Cretien van Campen, Alice de Boer, Sjoerd Kooiker, Kim Putters

c.van.campen@scp.nl; a.de.boer@scp.nl ; s.kooiker@scp.nl ; k.putters@scp.nl

In deze bijdrage van het Sociaal en Cultureel Planbureau (SCP) gaan we in op hoe de participatiesamenleving in de toekomst zal zorgen voor de groeiende groep ouderen. 'Zorgen voor' vatten we breed op en omvat niet alleen professionele gezondheidszorg, maar ook het zorgen voor zieke vrienden, buren en familie. In deze bijdrage schetsen we toekomstbeelden en kwesties. We baseren ons op het werk van anderen en maken geen trendextrapolaties, prognoses, scenario's of ramingen. Onderscheidend aan de SCP-benadering (vergeleken met andere instituten die de toekomst van de gezondheidszorg onderzoeken) is het burgerperspectief op zorgen thuis en de intersectorale doorkijk naar andere domeinen van het leven zoals leren, werken en samenleven.

\section{Veelkleurige vergrijzing}

Het aantal 75-plussers zal tot 2050 meer dan verdubbelen tot ongeveer 3 miljoen personen. ${ }^{1} \mathrm{Nu}$ al zijn de 100-plussers de snelst groeiende leeftijdsgroep. Het scenario met lage economische groei van Toekomstverkenning Welvaart en Leefomgeving door het Planbureau voor de Leefomgeving (PBL) en het Centraal Planbureau (CPB) veronderstelt dat de groei van de institutionele bevolking in bijvoorbeeld verpleeginstellingen beperkt zal zijn tot ongeveer 250.000 in 2050 bij een aantal 75plussers van 2,64 miljoen. ${ }^{2}$ Het hoge groeiscenario gaat uit van 350.000 ouderen in de intramurale zorg en 3,1 miljoen 75-plussers in 2050. Het aantal migrantenouderen neemt volgens deze toekomstverkenning toe. De bevolkingssamenstelling lijkt de komende decennia dus getypeerd te zullen worden door meer ouderen en een grotere etnische diversiteit. ${ }^{3}$ De gevolgen van de vergrijzing voor het zorgen voor elkaar worden duidelijker wanneer we naar generaties en levensfasen van ouderen kijken. De participatiesamenleving anno 2016 is gebaseerd op een grote groep mensen, bestaande uit de babyboomers en de vijftigplussers. De komende decennia zijn zij een belangrijke bron van sociaal kapitaal en ze zijn bovendien door het gestegen opleidingsniveau hoger opgeleid dan vorige generaties ouderen. ${ }^{4}$ In 2036 zullen de babyboomers van 194690 jaar worden en zal ondanks welke medische vooruitgang dan ook een flink deel zorgafhankelijk zijn. De babyboomers die momenteel veel informele zorg verlenen, zullen waarschijnlijk tegen die tijd zelf zorgvragers geworden zijn.

Hoewel velen hun zorgproblemen zelf zullen kunnen oplossen, zal ook een substantieel deel over een beperkt sociaal netwerk beschikken: nu al heeft één op de vijf 65-plussers niemand in het sociale 
netwerk die informele hulp zou kunnen bieden of die kan helpen de weg te vinden die naar zorg leidt. ${ }^{5}$ In 2036 zijn er naar verwachting wel veel vitale ouderen van rond de 70 jaar die dan nog de participatiesamenleving kunnen vormgeven. Verder vooruitkijkend wordt het perspectief voor de participatiesamenleving echter steeds minder gunstig. Aan het begin van 2050 zal bijvoorbeeld de grote geboortejaargang van 1964 (251.000 geboorten) 85 jaar geworden zijn. Latere jaargangen met minder geboorten (b.v. 1983, met 170.000 geboorten; zij worden 67 jaar in 2050), vormen dan waarschijnlijk de leeftijdsgroep van de mantelzorgers en zorgvrijwilligers. Van hen zal worden gevraagd om het oudere leeftijdscohort van informele hulp te voorzien.

Uitdaging voor de toekomst: veel ouderen, weinig zorgenden

We krijgen te maken met een groeiende groep hulpbehoevende 75-plussers en een afnemende groep mantelzorgers om voor hen te zorgen. De huidige generatie mantelzorgers wordt ouder en gaat na verloop van tijd zelf tot de groep zorgbehoevenden behoren. Zorgprofessionals worden steeds duurder en zullen eerder minder dan meer beschikbaar zijn, als de overheid op het beheersen van de zorgkosten blijft inzetten. Het is bovendien aannemelijk dat de trend van beperking van intramurale capaciteit in zorginstellingen wordt voortgezet. De zorgbehoevende ouderen wonen vooral aan dunbevolkte randen van Nederland, terwijl de potentiële jonge zorgaanbieders naar de stad vertrekken. In 2010 waren er voor elke baan in de ouderenzorg gemiddeld 27 potentiële arbeidskrachten beschikbaar, maar dit zullen er in 2040 gemiddeld nog veertien zijn. ${ }^{6}$ Zijn deze problemen op te lossen? De hoop lijkt gevestigd op vijf ontwikkelingen: technologische vooruitgang, aanpassing van het zorgstelsel, nieuwe vormen van wonen en zorg, burgerinitiatieven, en flexibilisering van de arbeid. ${ }^{7}$ Op de laatste twee oplossingen gaan we hier nader in.

\section{Burgerinitiatieven}

Er ontstaan de laatste decennia steeds meer buurtinitiatieven en zorgcoöperaties, met ondersteuning van vrijwilligers voor bijvoorbeeld een rit naar het ziekenhuis. Van deze samenwerkingsverbanden tussen zorgprofessionals en burgers wordt veel verwacht, maar het aantal succesvolle burgerinitiatieven en zorgcoöperaties blijft vooralsnog beperkt. Het is de vraag of er in de toekomst een grotere rol voor dergelijke initiatieven zal zijn weggelegd. Er zijn ook burgerinitiatieven op het terrein van wonen en zorg. Deze wijzen op nieuwe vormen van saamhorigheid en solidariteit die zorg- en woonproblemen zonder (of met geringe) inmenging van de overheid kunnen oplossen. Het risico is dat deze initiatieven vooral 'ons soort mensen' met elkaar verbindt en dat de minder 'aaibaren' buiten de boot vallen. In de steden is de kans groter dan in dorpen dat kwetsbare ouderen vergeten worden. Burgerinitiatieven vragen bovendien om de juiste sociale vaardigheden van burgers, niet te veel belemmerende regels en om een goede mix van jong en oud (niet alleen oude 
en hulpbehoevende, maar ook jonge en vitale deelnemers). Het schrikbeeld is dat gezonde burgers zich organiseren maar de sociaal geïsoleerde 75-plussers afhaken en er een heel ongelijke verdeling van burgerinitiatieven over het land ontstaat. Vinden mensen zulke nieuwe tweedelingen acceptabel? En welke nieuwe vormen van solidariteit vraagt dit? Hoe wordt de kwaliteit van zorg geborgd in deze initiatieven en welke kwaliteit van leven zullen de kwetsbare ouderen houden wanneer, omdat ze bijvoorbeeld minder aaibaar zijn of niet tot 'ons soort mensen' horen, niet meedoen in de zorg- en buurtinitiatieven?

\section{Flexibilisering van werken en zorgen}

Een gedachte is dat de zorg voor de grote groep 75-plussers in de toekomst opgevangen gaat worden door mantelzorg omdat er meer ruimte ontstaat om werk en privé te combineren. Gaat het combineren van werken en zorgen inderdaad zo moeiteloos als wel wordt aangenomen? $\mathrm{Nu}$ is het helpen voor sommige taakcombineerders al met stress en ziekteverzuim verbonden, met mogelijk burnout als gevolg. ${ }^{8}$ Vrouwen geven nu reeds vaker mantelzorg dan mannen en combineren dat vaak met een betaalde baan. Zal deze 'genderkloof' verder toenemen, omdat vrouwen door toenemende druk (op de korte termijn) tijdelijk minder gaan werken om te kunnen blijven zorgen en daarmee (op de lange termijn) minder pensioen opbouwen? Of zullen we zien dat mannen en vrouwen in gelijke mate meer gaan doen in mantelzorg en werk? In hoeverre zullen genderverschillen in het zorgen kunnen worden overbrugd door flexibele werktijden en mantelzorgvriendelijke werkgevers en door een goede verdeling van werk- en zorgtaken binnen het gezin? Hoe de antwoorden op deze vragen ook precies mogen luiden, er lijkt in de toekomst sowieso meer van burgers te worden gevraagd. Onduidelijk is echter waar de grens zal liggen. Omdat de overheid doelen stelt op het terrein van mantelzorg, economische zelfstandigheid van vrouwen, pensioenleeftijd en voorzieningen aanbiedt die de keuze tussen werk en mantelzorg faciliteren, is het ook aan de overheid om duidelijkheid te bieden omtrent de ruimte voor burgers om arbeid en mantelzorg te combineren. Als zorgverplichtingen net zo belangrijk worden geacht als arbeidsverplichtingen, dan zal de vraag naar de combineerbaarheid van taken nog meer dan nu het geval is actueel worden. Als zorgverplichtingen voorrang zouden krijgen, dan zou het kunnen gebeuren dat sommige intensieve helpers zich aan de arbeidsmarkt zullen gaan onttrekken. Als we willen dat iedereen die kan werken dit ook doet, dan is de verwachting dat mantelzorg niet altijd beschikbaar zal zijn en andere hulp moet worden ingeschakeld.

\section{Conclusie}

Naar de toekomst toe blijft het belangrijk dat ouderen over voldoende inkomen en sociale netwerken beschikken om eenzaamheid te voorkomen en toegang tot zorg zeker te stellen. Meer 
nog dan het bezitten van die hulpbronnen verwachten wij echter dat het er sterker om zal gaan of de ouderen daarmee ook geholpen zullen zijn. Bieden de sociale netwerken ook echt toegang tot (mantel)zorg, of tot hulp om bijvoorbeeld je weg te vinden in de bureaucratie van regelingen? Het betreft een verschuiving van de 'have \& have nots' onder de ouderen naar de 'cans \& cannots'. Zullen de vaardigheden en netwerken, maar ook het inkomen, voldoende zijn om de toegang tot zorg zeker te stellen en bijvoorbeeld eenzaamheid te voorkomen? Dit zal nadrukkelijker op de agenda komen, omdat alleen een inkomensregeling, een goede buur of een fijne werkgever niet automatisch voldoende soelaas bieden. Onderliggend raakt dat een fundamenteel vraagstuk rond de ordening van onze samenleving. Want: is hier een extra rol voor de overheid bij weggelegd? Moeten mensen hier - al ver voor hun hoge leeftijd - eigen verantwoordelijkheid voor nemen, b.v. door te blijven werken aan je sociale netwerken of aanpassingen in de woning tijdig te realiseren? Moeten buurten en families hier meer op aangesproken worden? Het antwoord op deze vragen kan politiek heel verschillend worden ingevuld, omdat het om een visie op de ordening van onze maatschappij gaat. Het beroep op mantelzorg is dan ook meer dan een ontlasting van professionals of het vergroten van de betrokkenheid van families. Juist in een verkiezingsjaar past het bevragen van die onderliggende visie op de relaties tussen burgers, overheid en samenleving in het publieke en politieke debat.

\section{Noot}

Deze bijdrage is gebaseerd op het hoofdstuk 'Zorgen; Hoe gaan we als samenleving zorgen voor de groeiende groep ouderen?' in het Sociaal en Cultureel Rapport 2016. ${ }^{7}$ 


\section{Mantelzorg op de drempel van pensioen}

Kène Henkens en Hanna van Solinge

Henkens@nidi.nl, solinge@nidi.nl

Het Nederlandse pensioenlandschap is sterk in beweging. Werknemers geboren in of na 1950 werden binnen een relatief kort tijdsbestek geconfronteerd met een aantal ingrijpende wijzigingen in de pensioenregelingen. In 2006 werden de fiscale faciliteiten om te stoppen met werken vóór het $65^{\text {ste }}$ jaar afgeschaft, en in 2012 werd besloten om de AOW-leeftijd stapsgewijs te verhogen tot 67 jaar (en daarna te koppelen aan de levensverwachting). Voor grote groepen werknemers is daarmee de pensioendatum waarop men zich al jaren richtte, vrij abrupt uit zicht geraakt. Deze verschuiving van de pensioenleeftijd heeft gevolgen voor de beschikbaarheid van mantelzorgers. Onderzoek heeft laten zien dat na pensionering de kans toeneemt dat mensen actief worden als mantelzorger. Van veel mantelzorg kan echter worden verondersteld dat het vraag gedreven is; het is niet zo zeer een 'vrije keuze' maar men wordt met een hulpvraag geconfronteerd. Er kan sprake zijn van (sociale) druk vanuit het familienetwerk die ervoor zorgt dat mensen 'weinig te kiezen hebben', bijvoorbeeld wanneer er acuut zorg nodig is, of er geen alternatieve mogelijkheden beschikbaar zijn. Ook de institutionele context kan ertoe bijdragen dat de keuzevrijheid van individuen ten aanzien van het aangaan van bepaalde rollen beperkt is. Het feit dat ouderen van nu veel langer actief blijven in betaald werk doet vermoeden dat veel meer ouderen kort voor hun pensioen met een combinatie van betaald werk en mantelzorg worden geconfronteerd. Recent onderzoek onder 6800 werknemers van 60 jaar en ouder (zie de box) laat zien dat veel van hen actief zijn als mantelzorger, maar voor een aanzienlijke groep vormt het een zware belasting. De flexibiliteit die de werksituatie en pensioenregeling biedt om belasting te verminderen is voor veel ouderen beperkt. ${ }^{9}$

\section{NIDI Pensioen Panel Onderzoek}

Het NIDI is in 2015 gestart met een nieuw onderzoek onder oudere werknemers. Aan het onderzoek werd deelgenomen door circa 6.800 werknemers (55\% mannen en $45 \%$ vrouwen) van 60 jaar en ouder aangesloten bij drie grote pensioenfondsen in Nederland. De pensioenfondsen vertegenwoordigen de sectoren overheid, onderwijs, zorg, welzijn en bouw. Het doel van het onderzoek is om inzicht te krijgen in het pensioneringsproces en de krachten die daarop van invloed zijn. 
Mantelzorg door 60-plus werknemers

Het doen van mantelzorg is bij werkende 60-plussers allerminst uitzonderlijk. Bijna de helft van hen combineert betaald werk met zorg voor anderen in de vorm van lichamelijke verzorging of huishoudelijke hulp aan iemand uit de naaste omgeving die ziek of hulpbehoevend is. Ongeveer 12 procent van de ondervraagde werknemers doet dit dagelijks of meerdere keren per week. Het gaat in de meeste gevallen om hulp die wordt geboden aan de partner of de (schoon)ouders. Het bieden van mantelzorg heeft duidelijk verschillende kanten. Aan de ene kant vindt driekwart van de ondervraagden het leuk om te doen. Aan de andere kant is het zwaar, stressvol en verplichtend in ongeveer één op de drie gevallen. De negatieve kanten van mantelzorg worden veel sterker gevoeld bij oudere werkende vrouwen. Deze belasting kan het gevolg zijn van de activiteiten die als mantelzorger worden verricht, maar ze hangen ook samen met de werksituatie en met de belastbaarheid van de zorgverlener zelf. Oudere werknemers die zelf gezondheidsklachten hebben zijn vaker actief als mantelzorger en ervaren het ook als meer belastend. Ook mensen die hun eigen werksituatie als stressvol ervaren (dat geldt voor $40 \%$ van alle 60 -plussers in het onderzoek) hebben meer problemen met de belasting die mantelzorg met zich meebrengt. Voor deze mensen is er duidelijk sprake van een combinatieproblematiek. Men is zelf al niet al te gezond en kampt zowel op het werk als thuis met een hoge belasting.

\section{Flexibiliteit in organisaties en pensioen}

Een belangrijke vraag is hoe belasting eventueel kan worden gereduceerd of gereguleerd. In ons onderzoek hebben we daarbij vooral gekeken naar de mogelijke flexibiliteit op de werkvloer. Flexibiliteit in werktijden en de mogelijkheid thuis te werken kan mensen helpen werk en mantelzorg makkelijker te combineren. Ook deeltijdpensioen of vervroegd pensioen kunnen een uitkomst bieden in situaties waarin mantelzorg erg tijdsintensief is. De flexibiliteit die mensen hebben binnen organisaties verschilt echter sterk. Het ene werk is het andere niet en lang niet iedereen heeft evenveel mogelijkheden werk met andere activiteiten te combineren. Ongeveer de helft van de ondervraagden geeft aan dat thuiswerken en deeltijdpensioen niet mogelijk is. Het valt daarbij op dat voor mantelzorgers die werken in kleine organisaties het aantal vrijheidsgraden beperkter is. Daarnaast is het de vraag of de bestaande mogelijkheden optimaal benut worden omdat er ook informele drempels kunnen zijn die mensen weerhouden veel flexibiliteit van hun werkgever te vragen. Ten aanzien van pensionering blijkt dat met het verdwijnen van vervroegd pensioen flexibiliteit in het uittredeproces is afgenomen. Bij veel ouderen bestaat een sterke wens om ruim voor hun AOW-leeftijd te stoppen met werken, maar men verwacht door te moeten werken tot $66 .{ }^{10}$ De discrepantie zien we ook sterk bij mantelzorgers. Ongeacht gezondheid, werkbelasting en 
belasting door mantelzorg verwacht men gemiddeld pas op 66-jarige leeftijd met pensioen te kunnen. Dit staat in groot contrast met een gewenste pensioenleeftijd die tweeëneenhalf jaar lager ligt. Ook mogelijkheden voor deeltijdpensioen - die in veel pensioenregelingen worden geboden worden nog weinig gebruikt en wellicht gekend.

\section{Conclusie}

Het beeld dat uit ons onderzoek naar voren komt is dat er een duidelijke roep is om een meer flexibel pensioen dat mantelzorgers in staat stelt betaald werk en mantelzorg makkelijker te combineren (deeltijdpensioen) dan wel te reguleren door wat eerder met werken te kunnen stoppen. 


\section{Informele en formele zorg: over grenzen}

Henk Nies (h.nies@vilans.nl; h.l.g.r.nies@vu.nl)

We hebben het in de zorg vaak over 'de driehoek' van de cliënt of patiënt, de mantelzorger en de professionele zorgverlener. Het lijken onderscheiden rollen met onderscheiden verantwoordelijkheden die in een zekere harmonie opereren. Maar de 'pootjes' van de driehoek zijn niet altijd even lang. De werkelijkheid is vaak veelhoekiger of soms zelfs gewoon 'hoekig'. Een voorbeeld daarvan beschreef onlangs sportarts Jos Benders in zijn boek 'Liefde met voorbedachten rade'. ${ }^{11}$ Over een periode van ruim vier jaar zorgde hij voor zijn moeder die na een CVA weer thuis ging wonen. Met twaalf helpers (gediplomeerd en ongediplomeerd) en tien behandelaren organiseerde hij 23 uur zorg per dag in een 'éénpersoonskliniek'. Benders was niet alleen zoon, maar ook manager, werkgever, financier, ethicus, zaakwaarnemer, gemachtigde, uitvoerder, behandelaar en privé-detective (hij moest ook enkele gevallen van diefstal oplossen). Het zijn rollen waar verschillende competenties voor nodig zijn en met een eigen verantwoordelijkheid, soms als mantelzorger, soms als professioneel zorgverlener en soms als vertegenwoordiger van de cliënt.

\section{De complexiteit en urgentie van het vraagstuk}

In veel langdurige zorgsituaties is de situatie veel complexer dan de driehoek suggereert. Er zijn immers vaak ook vrijwilligers en burgers in algemene zin actief, soms op individueel vrijwillige basis, soms met een vergoeding uit het persoonsgebonden budget. En dan zijn er nog burgerinitiatieven, waar burgers collectief zorg organiseren. In de formele zorg zien we eveneens een brede schakering van professionals met uiteenlopende professionele achtergronden en bijbehorende paradigma's, identiteiten, werkculturen, organisatievormen, wetgeving en financieringsvormen. Deze professionals komen lang niet altijd harmonisch bij elkaar. ${ }^{12} \mathrm{En}$, om het nog ingewikkelder te maken, zijn de hulpvragen van veel mensen niet altijd eenduidig en consistent. Ze fluctueren in de tijd en vaak zijn er meer goede antwoorden op dezelfde vraag mogelijk. Hoe kunnen we het samenspel beter begrijpen en meer inzicht krijgen in de mechanismen die ertoe bijdragen dat de verschillende betrokkenen tot constructieve samenwerking komen?

\section{Betekenisgeving}

Gedeelde betekenisgeving aan de relatie en de situatie is van belang, wil een goed samenspel tot stand komen. Allereerst is inzicht nuttig in de overwegingen van mensen om hulp te verlenen, hun antwoorden op de kernvragen: 'Wat is nodig?', 'Wat wil ik?', 'Wat kan ik?' en 'Wat doen anderen?'. ${ }^{13}$ Onderliggend is de vraag naar betekenisgeving aan de relatie en de situatie. Niet iedereen geeft daar hetzelfde antwoord op. Verschillende verwachtingen, opvattingen en normen spelen daarbij een rol. 
We zien dat al wanneer het gaat om het ondersteunen van zelfmanagement. Voor de ene hulpverlener betekent dat dat hij of zij de cliënt instrueert professionele standaarden toe te passen. Voor de andere hulpverlener betekent het met de cliënt aan goede voorwaarden te werken zodat deze naar eigen inzicht een goed leven kan leiden, met zelfbepaling en autonomie. ${ }^{14}$

\section{Identiteit}

Het roept de vraag op of we in het debat over mantelzorg niet te eenvoudig aannemen, dat er cliënten, mantelzorgers, vrijwilligers, burgers, professionals zijn met eigen onderscheiden rollen en karakteristieken. Hebben zij een eigen eenduidige identiteit? Het interessante van het begrip 'identiteit' is dat het enerzijds duidt op identificatie met de ander en anderzijds op het streven naar autonomie en separatie van die ander. ${ }^{15}$ Identiteit krijgt vorm in relatie tot de ander. Het is een dynamisch begrip, dat meebeweegt met de persoon, die meebeweegt (of soms tegen-beweegt) met wat er in de omgeving gebeurt. Het is een relationeel begrip dat gaat over verbinden en onderscheiden in waarden en opvattingen. En dan kunnen rollen en identiteiten ook nog eens door elkaar lopen. Een heel nuchter feit is dat meer dan 15\% van de beroepsbevolking in de zorg werkt; dus misschien ook wel 15\% van de mantelzorgers. En dan is er ook nog een behoorlijke groep vrijwilligers die in de zorg werkt of heeft gewerkt. Kortom, de domeinen formele en informele zorg kennen open grenzen.

\section{Grenzen}

Het organisatiekundige begrip 'boundary work' gaat juist over het grensverkeer en de afbakeningen, die gehanteerd worden. Het gaat ook over het vervagen van grenzen en het bevechten van grenzen. Je kunt naar grenzen kijken als het resultaat van interacties tussen mensen en dus ook organisaties, maar ook als de bron van die interacties. ${ }^{16}$ Het stellen van grenzen definieert 'insiders' en 'outsiders', 'wij' en 'zij'. Als we naar een goed samenspel van zorgverleners toe willen, dan is het zinvol te kijken naar hoe we grenzen aanbrengen en hoe grenzen ons laten belemmeren. Het gaat erom dat we rond complexe zorgsituaties goede teams maken: informeel, formeel, betaald, niet-betaald, emotioneel verbonden, instrumenteel verbonden. Het gaat er om onderlinge afhankelijkheden te organiseren, dat mensen creatieve oplossingen creëren en dat daarover goede besluitvorming tot stand komt. ${ }^{17}$

\section{Conclusie}

Bij samenspel draait het om de betekenisgeving aan een complexe zorgsituatie en zorgrelatie. Daar kunnen mensen verschillend inzitten, vanuit een verschillende identiteit die niet per se als formeel of informeel geduid moet worden. De grenzen bepalen we voor een deel zelf en of we daar goed mee 
om gaan hangt af van of het lukt om goede condities voor samenwerking te scheppen. Dat gaat niet vanzelf goed. Misschien dat voorlopig de volgende ezelsbruggetjes helpen!

\section{6 ezelsbruggetjes voor een goede dialoog}

(bron: http://www.vilans.nl/Tips-6-ezelsbruggetjes-voor-een-goede-dialoog.html)

1. Gebruik LSD: Luisteren, Samenvatten, Doorvragen

Vat het verhaal kort samen en laat de ander reageren. Vraag door als iets onduidelijk is.

2. Laat OMA (wat vaker) thuis: Oordelen, Meningen, Adviezen

Als iemand iets vertelt, laat dan eigen oordelen, ideeën en adviezen even voor wat ze zijn, zodat $u$ met een open houding kunt luisteren.

3. Neem ANNA mee: Altijd Navragen, Nooit Aannemen

Neem niet zomaar aan dat u begrijpt wat iemand bedoelt. Vraag bij twijfel altijd even na of het klopt.

4. Smeer NIVEA: Niet Invullen Voor Een Ander

Als iets niet duidelijk is, of als we iemand al lang kennen, vullen we al snel andermans bedoelingen zelf in. Dit voorkomt u door na te vragen.

5. Wees een OEN: Open, Eerlijk, Nieuwsgierig

Sta open voor de ander, geef deze een kans iets uit te leggen en wees oprecht nieuwsgierig.

6. Maak je niet DIK: Denk in Kwaliteiten

Zeker bij wat moeilijke gesprekken kijken we al er snel naar wat fout ging. Dat mag, maar geef vooral aandacht aan wat goed gaat. 


\section{Zorgende families}

\section{Pearl A. Dykstra (dykstra@eesb.eur.nl)}

\section{Een zorgelijke toon}

De verdeling van de zorg voor ouderen tussen families en de overheid is een onderwerp dat al lange tijd belangstelling geniet van wetenschappers, beleidsmakers, politici en het brede publiek. Een zorgelijke toon overheerst in de discussies. Eén invalshoek is: overheidszorg is duur en met de komst van nog meer ouderen zullen de kosten alleen maar toenemen. Een andere redenering is: overheidszorg verdringt de zorg verleend door familieleden, hetgeen tot gevolg heeft dat de sociale cohesie in onze samenleving verzwakt omdat wederzijdse verplichtingen afnemen. ${ }^{18}$ Men spreekt bij deze laatste redenering ook wel van de 'crowding-out' hypothese (verdringingshypothese). Inmiddels is het denkbeeld dat genereuze overheidszorg familiezorg verdringt te ruste gelegd.

Landenvergelijkend onderzoek heeft herhaaldelijk aangetoond dat, in zoverre verdringing optreedt, deze vooral langdurige en zware vormen van zorg betreft. ${ }^{19}$ De beschikbaarheid van publieke zorg maakt het voor familieleden beter mogelijk om juist die zorg te verlenen waarvoor ze het beste geschikt zijn: emotionele steun en niet-gestandaardiseerde steun zoals begeleiding, vervoer en klusjes in huis. Geen verdringing van familiezorg door publieke zorg, maar complementariteit.

\section{Hervorming van de zorg}

Mede vanuit overwegingen van kostenbeheersing, is de organisatie van de langdurige zorg in Nederland veranderd. De recente hervormingen betreffen een vermindering van intramurale zorg, beperking en decentralisatie van lichtere vormen van zorg zoals huishoudelijke hulp, een sterkere gerichtheid op de meest behoeftigen, en verhoging van de eigen financiële bijdrage. Afgaande op cijfers van het Centraal Bureau voor de Statistiek (CBS) voor de periode 2004-2104, is het zorggebruik in overeenstemming met de beleidsdoelstellingen veranderd. Het aandeel ouderen dat publiek gefinancierde huishoudelijke hulp ontvangt, is afgenomen. De ontvangers krijgen gemiddeld meer uren huishoudelijke hulp-een aanwijzing dat de ontvangers vooral de meest behoeftigen zijn.

\section{Familiesolidariteit}

Representatieve cijfers over veranderingen in de zorg die door familieleden wordt verleend, zijn schaars. Gelukkig beschikken we over gegevens van de Netherlands Kinship Panel Study (NKPS), die een gestage toename laten zien tussen 2002 en 2014 in het aandeel volwassen kinderen dat huishoudelijke hulp verleent aan zorgbehoevende ouders. ${ }^{20}$ Zowel zoons als dochters zijn vaker hulp 
gaan verlenen. Intrigerend is dat de toename niet is toe te schrijven aan sterkere beperkingen onder de ouders. Evenmin blijkt die toename toe te schrijven te zijn aan minder gebruik van thuishulp. Toch zijn meer en meer volwassen kinderen hun ouders bij gaan staan-wellicht in reactie op het appel van de overheid om verantwoordelijkheid jegens hulpbehoevenden te tonen, of wellicht als uiting van een meer algemeen patroon van toenemende solidariteit in families. ${ }^{21}$

\section{Relatie publieke en familiezorg}

Met de opbouw van de welvaartstaat kwam de vraag of overheidsvoorzieningen de zorg door familieleden zouden verdringen. De huidige neoliberale hervormingen van de welvaartstaat brengen de tegengestelde vraag: doen zorgende families de noodzaak van publiek gefinancierde zorg afnemen? Door NKPS-gegevens te combineren met CBS-registerdata over het gebruik van voorzieningen van de Algemene Wet Bijzondere Ziektekosten (AWBZ), kan die vraag vooralsnog negatief worden beantwoord: ${ }^{22}$ Het zorggebruik van ouderen blijkt niet samen te hangen met de huishoudelijke hulp die ze van een willekeurig geselecteerd volwassen kind krijgen. Wel tonen de resultaten dat oudere mannen met een partner minder gebruik maken van AWBZ-zorg. Onder oudere vrouwen is er geen verschil in zorggebruik tussen degenen met en degenen zonder een partner. Twee interpretaties zijn mogelijk. De eerste is dat er een seksevooroordeel is in de behandeling van aanvragen voor publieke zorg-wellicht worden oudere mannen als minder geschikte verzorgers beschouwd. De tweede is dat oudere mannen de zorgvaardigheden ontberen, of denken die te ontberen, die vrouwelijke partners wel hebben. Voorzichtigheid is geboden. Mogelijk verschilt de implementatie van overheidsregelingen, afhankelijk van de sekse van de oudere cliënt.

\section{Overheidsbeleid en gender}

Genderverschillen kunnen onbedoeld het gevolg zijn van de wijze waarop overheden beleid rond zorg voor oud en jong organiseren. ${ }^{23}$ Overheidsbeleid kan ongewenste afhankelijkheden binnen families creëren (familialism by default), de keuze om zorg te geven vergemakkelijken (supported familialism) en economische zelfstandigheid bevorderen (defamilialisation). Ook is het type voorziening van belang vanwege mogelijk verschillende implicaties voor sekse- en sociaaleconomische ongelijkheden. ${ }^{24}$ Vrouwen zullen bijvoorbeeld eerder dan mannen kiezen voor financiële vergoedingen, net zoals vrouwen met weinig beroepsperspectieven eerder die keuze zullen maken dan vrouwen met ruime beroepsperspectieven. Financiële vergoedingen voor familiezorg herbergen aldus het risico van onvoldoende economische zelfstandigheid. Diensten in de vorm van thuiszorg en dagopvang stellen mannen en vrouwen beter in staat om zorg- en arbeidstaken te combineren. 


\section{Conclusie}

Het is niet duidelijk of de toename van familiesolidariteit het gevolg is van de afname van publiek betaalde zorg. Bij de vormgeving van beleid is het cruciaal om alert te zijn op mogelijke ongewenste afhankelijkheden binnen families-tussen jong en oud, en tussen mannen en vrouwen. 


\section{Mantelzorg: Veerkrachtig of weerbarstig?}

\section{Marjolein Broese van Groenou (m.i.broesevangroenou@vu.nl)}

Mantelzorg is inmiddels niet meer weg te denken uit onze samenleving: iedereen weet nu wat ermee bedoeld wordt, hoe vaak het voorkomt, waarom men al dan niet mantelzorg geeft, en wat de grootste valkuilen zijn van mantelzorg (overbelasting!). Met de vergrijzing en huidige ontwikkelingen in de (ouderen)zorg ligt er een belangrijke nieuwe vraag voor de toekomst: kan onze samenleving wel voldoen aan de toenemende vraag om mantelzorg? De overige bijdragen van dit symposium gaan over de rol van werkgever, professionals, familie en beleid. Aan mij de taak om in deze bijdrage een visie neer te zetten over mantelzorg in de context van een snel veranderende samenleving: is het nodig dat mantelzorg verandert? En zo ja, hoe dan? In hoeverre is mantelzorg een weerbarstig construct, dat wil zeggen onveranderlijk en inflexibel, of is het veerkrachtig genoeg om zich aan te passen aan de eisen die de toekomstige samenleving eraan stelt?

\section{Veerkracht en mantelzorg}

Veerkracht wordt gedefinieerd als het vermogen van een systeem (individu, buurt, organisatie, samenleving) om met ernstige verstoringen om te gaan, en aanpassingen te maken met behoud van de kernfuncties van het systeem. De uitkomst kan zijn: ofwel terug naar de status quo ofwel transformatie naar een nieuwe vorm met behoud van de kernfuncties van het systeem. ${ }^{25}$ Mantelzorg is een structureel onderdeel van onze samenleving en heeft een heldere kernfunctie: de zorg die men aan een naaste geeft als hij of zij door gezondheidsproblemen dagelijkse activiteiten minder goed kan verrichten. ${ }^{26} \mathrm{Er}$ zijn (minstens) twee concrete 'verstoringen' aan te geven waardoor het aandeel van mantelzorg in de samenleving onder druk staat: de toenemende vergrijzing en het terugdraaien van collectieve voorzieningen, waardoor kwetsbare groepen steeds meer op zorg in de eigen omgeving zijn aangewezen. Dit vergroot het risico op overbelasting en verminderde participatie in onderwijs en werk voor specifieke groepen in de samenleving. Om deze ongewenste uitkomsten te voorkomen, zullen we moeten herzien wie mantelzorg kan geven, hoe dit zich verhoudt tot de zorg die anderen geven, en wat er voor nodig is om mantelzorg langdurig vol te houden. Er zijn drie zaken nodig om mantelzorg een veerkrachtig onderdeel van onze samenleving te doen zijn.

\section{Kern-mantelzorgers}

Ten eerste dienen we nader te bepalen wie we als mantelzorger aanmerken en wie niet. Veerkracht moet vooral getoond worden door degenen die het eerst en meest met de hulpbehoefte van een 
naaste geconfronteerd worden, zoals partners, ouders, kinderen, of, ingeval van alleenstaanden en kinderlozen, andere familieleden, buren of vrienden met een sterke band met de zorgbehoevende. Dit zijn degenen die vaak langdurig en intensief betrokken zijn in de zorgverlening ${ }^{26}$ en van wie we verwachten dat ze het lang volhouden. Uit onderzoek naar zorgnetwerken weten we dat het overgrote merendeel van de ouderen meerdere mantelzorgers heeft, ${ }^{27}$ maar dat er een duidelijk verschil bestaat tussen kern-mantelzorgers die sterk betrokken zijn en/of veel uren helpen, en anderen die vooral als 'hulp-mantelzorgers' kunnen worden beschouwd omdat ze af en toe inspringen. De laatsten zijn heel belangrijk, maar trekken niet de kar. Helpers vanuit vrijwilligersorganisaties en nieuwe creatieve organisaties die betaalde mantelzorg aanbieden, vallen niet onder onze kerndefinitie van mantelzorg. Het gaat om de veerkracht van de kern-mantelzorgers, want zij zijn degenen die ondersteuning het meest nodig hebben.

\section{Verbreden en verdelen}

Ten tweede zou het aantal solitaire en overbelaste mantelzorgers af moeten nemen. Dit vereist een andere taakopvatting van de kern-mantelzorger, vooral voor de vele mantelzorgers die op afstand wonen en zorg met werk moeten combineren. Mantelzorgers worden van uitvoerders meer de regisseurs van de zorg: dit houdt in dat zij, samen met de zorgvrager, de kring van hulpverleners verbreden naar buren, vrienden, oud-collega's, vrijwilligers, studenten die voor studiepunten langskomen, betaalde krachten die met de zorgontvanger gaan wandelen, professionele krachten van de thuiszorg, noem het maar op. Daarbij kan de mantelzorger-op-afstand toch betrokken blijven, bijvoorbeeld dankzij: de student die voor zijn/haar opleiding de communicatie met moeder via skype op de ipad opstart; het appje van de thuiszorg dat meldt dat het vandaag goed is gegaan, en dat vader veilig in bed ligt met schone pyama aan; of de gymnastiekrobot die de dagelijkse oefeningen met moeder doorneemt en begint te piepen als ze het niet goed genoeg doet. Met het zorgverlof van de werkgever en af en toe wat respijtzorg, is de coördinatietaak langer vol te houden. Het bevorderen van veerkracht bij mantelzorgers betekent dus vooral het aanbod aan diverse vormen van hulp vergroten en zorgen dat mantelzorgers het zorgnetwerk kunnen opbouwen en onderhouden. (Voorwaarde is wel dat de zorgontvanger hier een beetje in meewerkt en al die nieuwe gezichten ook accepteert en binnenlaat!)

\section{Voorbereiden op mantelzorg}

Ten derde zal veerkracht zichtbaar moeten worden in hoe de burger zich zelf voorbereidt op het geven dan wel krijgen van mantelzorg. Het ontwikkelen van het zorgpotentieel in het eigen netwerk zal meer bewust deel uit moeten maken van het leven om voorbereid te zijn op de zorgvraag op de oude dag. Dit leidt tot een andere invulling van het leven na de 55 jaar dan wellicht voorzien: 
doorwerken tot 67 jaar, dan verhuizen richting de kinderen, en daar ter plekke nog een jaar of tien investeren in buurtgenoten, vrijwilligersorganisaties en nieuwe vrienden of kennissen, om het zorgpotentieel in het eigen sociaal netwerk zo groot mogelijk te maken. Maar dan is men terdege voorbereid op de eigen zorgvraag dan wel die van de partner, zo tegen het 75ste of mogelijk zelfs 80ste levensjaar. Dan is men of mantelzorger, of afhankelijk van een mantelzorger, of beide, en voorbereid om dat zorgnetwerk te regisseren!

\section{Conclusie}

Hoewel betrokkenheid en steun als kernfunctie van mantelzorg overeind zullen blijven, ziet mantelzorg anno 2030 er anders uit dan anno 2000, en zal de vormgeving ervan veel creatief organisatietalent vereisen om het langdurig vol te blijven houden. Het thema bindt families, buurten, opleidingen, werkgevers, en hulpverleners en dat moet zichtbaar worden in de zorgnetwerken van kwetsbare burgers. We willen af van de overbelaste, solitaire mantelzorger. Mantelzorg deel je, verdeel je, en beheers je. Dat is de mantelzorg van de toekomst! 


\title{
Wie maakt het verschil? Ongelijkheid in condities en consequenties van informele hulp
}

\author{
Alice de Boer (a.h2.de.boer@vu.nl; a.de.boer@scp.nl)
}

Dit is een samenvatting van de rede 'Wie maakt het verschil? Sociale ongelijkheid in condities en consequenties van informele hulp' die prof. Dr. Ir. Alice H. de Boer heeft uitgesproken bij de aanvaarding van het ambt van bijzonder hoogleraar Sociale ongelijkheid en informele hulp bij de Faculteit der Sociale Wetenschappen van de Vrije Universiteit Amsterdam op 26 januari 2017.

Momenteel zijn er in Nederland ruim vier miljoen mantelzorgers en bijna een miljoen vrijwilligers in de zorg en ondersteuning. In het publieke debat is er veel bezorgdheid over deze onbetaalde hulp aan hulpbehoevenden en over specifieke groepen die deze hulp geven. Er wordt gevreesd dat de druk van de participatiesamenleving en het sterkere beroep op de eigen verantwoordelijkheid van burgers tot een onevenredig grote informele inzet van sommige groepen zal leiden. Men noemt onder meer vrouwen, verschillende leeftijdsgroepen en migranten. Hoe staat het met de sociale ongelijkheid van de informele hulp en wie kan bijdragen aan het verminderen van de verschillen tussen groepen?

\section{Omvang}

Hoe groot zijn de verschillen tussen groepen in het geven van informele hulp naar sekse, leeftijd en herkomstgroepen? In Nederland geeft $37 \%$ van de vrouwen mantelzorg en $28 \%$ van de mannen. ${ }^{26}$ In absolute aantallen gaat het om 2,5 miljoen vrouwen en 1,8 miljoen mannen. Het is dus niet zo dat mannen het laten afweten, maar vrouwen nemen wel vaker deze hulp op zich. Mannen helpen vaker bij administratie of vervoer. Vrouwen helpen bij het regelen en coördineren van voorzieningen, bezoek aan arts, persoonlijke verzorging of emotionele steun. Mensen tussen de 35 en 64 jaar geven vaak hulp. Het gaat het vooral om hulp aan hun ouders of schoonouders. Toch zijn er ook jongeren die te maken hebben met een zorgtaak, omdat zij opgroeien met een ziek gezinslid, meestal een ouder of een broer of zus. Ook zijn er steeds meer oudere helpers. Zij zorgen voor hun partner of zeer oude ouders. Er wordt wel eens gedacht dat niet-westerse migranten vaak informele hulp bieden omdat zij veel gezondheidsproblemen ondervinden en grote families hebben. Uit recent onderzoek blijkt dat niet-westerse migranten echter minder vaak mantelzorg geven dan autochtonen of westerse migranten. Het verschil is ongeveer tien procentpunten. ${ }^{28}$

\section{Oorzaken}

Nu we weten dat vrouwen vaker hulp geven dan mannen, dat 35-64 jarigen relatief vaak hulpverleners zijn en migranten relatief weinig, roept dat de vraag op: wat maakt dat die ongelijkheid er is? Anders gezegd: onder welke voorwaarden kunnen en willen mensen uit bepaalde sociale groepen hulp bieden? De eerste verklaring voor sociale verschillen in het geven van informele hulp ligt in de noodzaak om te helpen. Vrouwen kennen vaker een hulpbehoevende dan mannen. Ze zeggen ook vaker dat ze aanvoelen of iemand hulp nodig heeft. Vrouwen hebben bovendien grotere en meer gemengde netwerken waardoor ze meer verzoeken om hulp krijgen. Daarnaast speelt leeftijd een rol: 45-64-jarigen kennen vaker dan gemiddeld een hulpbehoevende. Dit komt vooral doordat zij oude ouders hebben: bij de jongere groepen zijn ouders meestal nog gezond en bij de oudere groepen vaak niet meer in leven. In vergelijking met autochtonen hebben niet-westerse migranten minder vaak iemand in hun sociale netwerk die regelmatig hulp nodig heeft. Dit hangt 
voor een deel samen met leeftijd: niet-westerse migranten zijn gemiddeld jonger dan autochtonen en hebben daardoor ook minder vaak een partner of ouder op leeftijd. ${ }^{26}$

Een tweede verklaring waarom sommige groepen vaker hulp geven dan anderen hangt samen met hun opvattingen over mantelzorg. ${ }^{29}$ Een voorbeeld hiervan is de inschatting wie men het meest geschikt vindt voor een mantelzorgtaak. Vinden we dat vrouwen beter dan mannen geschikt zijn om die hulp te geven? Een kwart van de mannen is van mening dat vrouwen geschikter zijn om hun naasten te helpen. Bij vrouwen ligt dit aandeel lager. Mensen vinden dit vooral omdat zij menen dat vrouwen beter dan mannen aanvoelen dat mantelzorg nodig is, niet omdat ze meer tijd zouden hebben. De meerderheid van de vrouwen en ongeveer de helft van de mannen is het (helemaal) niet eens met deze stelling.

Een derde verklaring voor verschillen tussen groepen is dat sommige mensen meer of minder tijd hebben om te helpen. Uit onderzoek weten we dat mensen met veel werkuren minder vaak informele hulp verlenen dan anderen. Er zijn ook grote verschillen naar geslacht: drie kwart van de mannen combineert de mantelzorgtaak met een betaalde baan, bij vrouwen is dit nog geen derde. ${ }^{26}$ Het aandeel werkenden dat informele hulp geeft, nam tussen 2004 en 2014 toe, met zes procentpunten, zowel voor mannen als vrouwen. ${ }^{8}$ Het verschil tussen mannen en vrouwen blijft in deze periode ongeveer gelijk (verschil is ongeveer acht procentpunten). Onder de werkenden is er dus geen toename (of afname) in sekseongelijkheid in de informele hulp.

\section{Gevolgen}

Als burgers uit de ene sociale categorie meer tijd heeft voor het geven van hulp dan de andere, dan wel meer oog heeft voor de noden van naasten is dat niet automatisch een probleem dat moet worden opgeheven. De sociale ongelijkheid is vooral onwenselijk als de negatieve consequenties van het helpen bij bepaalde groepen in de bevolking vaker voorkomen dan bij anderen. Bijvoorbeeld als het helpen gevolgen heeft voor het welbevinden, ervaren belasting, werk of opleiding. Sociale verschillen in de informele hulp gaan dan ook niet alleen over ongelijke condities, maar ook over ongelijke consequenties.

Een op de tien mantelzorgers geeft aan zwaar belast te zijn door de hulptaak. Deze mantelzorgers rapporteren dat de situatie van de hulpbehoevende hen nooit loslaat of dat de hulp te veel op hun schouders terechtkomt. Dit zijn 400.000 volwassenen in Nederland..$^{30} \mathrm{Al}$ eerder zagen we dat vrouwen oververtegenwoordigd zijn onder de helpers. Ook voelen vrouwen zich, als zij eenmaal hulp geven, zwaarder belast door de zorgtaak dan mannen. Sommige leeftijdsgroepen vinden het geven van hulp zwaarder dan anderen. 35-44-jarigen ondervinden relatief vaak een hoge belasting. Maar ook scholieren met een ziek gezinslid oordelen ongunstiger over hun psychisch welbevinden dan leeftijdsgenoten. ${ }^{31} \mathrm{Er}$ zijn indicaties dat mantelzorgers met een migrantenachtergrond niet alleen vaak intensief en langdurig helpen, maar dat zij zwaar belast zijn. ${ }^{32}$ Dit kan voortkomen uit hoge verwachtingen die sommige herkomstgroepen hebben over de hulp die zij aan hun ouders moeten geven. ${ }^{33}$ Niet-westerse migranten zouden minder vaak professionele steun en mantelzorgondersteuning ontvangen; dit zou een extra oorzaak kunnen zijn voor hun hoge belasting.

Werkenden met een mantelzorgtaak, zeker met een intensieve of langdurige taak, lopen meer risico om gezondheidsproblemen te ontwikkelen en zich op het werk ziek te melden dan andere werkenden. Dit geldt zowel voor intensieve helpers als voor mensen die langdurig hulp geven. ${ }^{8}$ In 
2014 is een op de tien werkende mantelzorgers (tijdelijk of structureel) minder gaan werken of gestopt met werken vanwege de mantelzorgtaak (ruim 270.000 mensen). ${ }^{26}$ Vrouwen en mannen hebben hier in gelijke mate mee te maken. Verzorgers van partners en kinderen nemen deze ingrijpende maatregel ongeveer twee maal zo vaak als helpers van een (schoon)ouder. Vooral mensen die regelmatig hun werk moeten onderbreken voor de hulpbehoevende, zijn vaak gestopt.

Uit verschillende onderzoeken onder jonge mantelzorgers blijkt dat jongeren problemen ervaren bij het volgen van hun opleiding. Cijfers afkomstig van het scholierenonderzoek Health Behavior in School-aged Children 2013 laten zien dat scholieren met een ziek gezinslid even vaak spijbelen als hun leeftijdsgenoten. Maar àls jongeren met een ziek gezinslid spijbelen dan doen ze dat meer uren. Uit de Studentengezondheidstest van de studentenartsen van de UvA blijkt dat mantelzorgende studenten relatief vaak vertraging in hun studie oplopen. ${ }^{34}$

\section{Wie maakt het verschil?}

Wie kan bijdragen aan de vermindering van deze vormen van sociale ongelijkheid? Anders gezegd: wie maakt het verschil? Allereerst kunnen mantelzorgers en hun hulpbehoevenden zelf het verschil maken door tijdig hulp in te roepen. Bijvoorbeeld door zelf actiever op zoek gaan naar mensen met wie zij de hulp kunnen delen. Ik denk hierbij niet alleen aan familie, maar ook mensen in andere netwerken waarin zij actief zijn. Deze 'omstanders' zouden actief hulp kunnen aanbieden. Zo maken vele handen licht werk en ondervinden mensen mogelijk ook minder negatieve ervaringen. Delen van de zorg werkt verlichtend.

Daarnaast kunnen allerlei organisaties zoals werkgevers, onderwijsinstellingen, gemeenten en thuiszorgorganisaties helpen bij het verminderen van de belasting van helpers. Wat doen zij momenteel aan ondersteuning? Werkgevers dragen bij aan de mogelijkheden om werk en zorg te combineren. Ik denk dan aan het toepassen van verlofregelingen, maar ook om het bespreekbaar maken van een zorgtaak, tonen van begrip en het bieden van mogelijkheden om flexibel te kunnen werken als de mantelzorgsituatie daarom vraagt. Onderzoek laat zien dat het belangrijk is dat mensen onverwachts een dag vrij kunnen nemen of deels hun eigen werktijden kunnen bepalen. ${ }^{26}$

Op de middelbare school en in het vervolgonderwijs lijkt er nog nauwelijks aandacht voor jonge mantelzorgers. Docenten, leerkrachten, zorgcoördinatoren, tutoren en mentoren kunnen jonge mantelzorgers eerder signaleren, maar hen ook een luisterend oor en meer flexibiliteit in roosters, tentamens en opdrachten bieden.

Vanaf 2015 zijn gemeenten nog belangrijker geworden voor de ondersteuning van mantelzorgers. Gemeenten hebben daar in de praktijk verschillende oplossingen voor. Tussen een vijfde en een kwart van de mantelzorgers ontvangt respijtzorg, dagopvang/behandeling, logeervoorziening, een vrijwilliger of een oppas. ${ }^{26}$ Ongeveer een vijfde ontvangt andere vormen van ondersteuning, zoals informatieadvies en materiële hulp. In veel gevallen komt ondersteuning pas in beeld als mensen al overbelast zijn. Degenen die ondersteuning nodig hebben, beseffen vaak onvoldoende dat dit mogelijk is en zullen meer proactief benaderd moeten worden door de mensen die contact met hen hebben.

Veel mantelzorgers delen de hulp die zij geven met anderen. Goed afstemmen en samenwerken is dan belangrijk. Een derde van de mantelzorgers vindt dat de thuiszorg of de wijkverpleegkundige 
onvoldoende oog heeft voor hoe het met de mantelzorger zelf gaat. ${ }^{26}$ Op dit punt is dus nog veel winst te behalen. Daarvoor is het wel noodzakelijk dat beroepskrachten voldoende tijd krijgen en deskundigheid hebben om dit te doen.

Hoewel de ondersteuning van informele helpers onder de verantwoordelijkheid van de gemeente valt, kan ook de rijksoverheid maatregelen treffen. Denk bijvoorbeeld aan maatregelen om de combinatie van mantelzorg en betaald werk te vergemakkelijken, zoals zorgverlof.

Er zijn nog veel meer actoren in het maatschappelijk middenveld betrokken bij de ondersteuning van mantelzorgers, zoals vrijwilligers- en welzijnsorganisaties, kerken en zorgcoöperaties. Hulp kan dan ook door heel veel mensen en organisaties geboden worden. Toch is er nog maar weinig zicht op hoe en door wie het verschil te maken is. Het is bijvoorbeeld niet duidelijk welke effecten verschillende interventies op het terrein van de informele hulp hebben en of vormen van ondersteuning anders uitwerken voor bijvoorbeeld mannen en vrouwen of voor verschillende migrantengroepen.

Tot slot

In het symposium over de toekomst van de informele zorg passeerden al enkele waardevolle suggesties voor toekomstig onderzoek de revue. Ik zou het geweldig vinden als we deze punten verder zouden kunnen uitwerken. Ik hoop met mijn leerstoel meer inzicht te kunnen verschaffen in het ontstaan van sociale ongelijkheid in informele hulp en manieren te vinden om de verschillen in de toekomst te verkleinen. 
Referenties

1. Doekhie K, De Veer A, Rademakers J, Schellevis F, Francke JP. Nivel Overzichtstudies. Ouderen van de toekomst. Verschillen in de wensen en mogelijkheden voor wonen welzijn en zorg. Utrecht: Nivel, 2014.

2. De Jong A. Toekomstverkenning Welvaart en Leefomgeving. Cahier Demografie. Den Haag: Planbureau voor de Leefomgeving en Centraal Planbureau, 2015.

3. Roeters A, Van den Broek A, Dagevos J, De Haan J, Wennekers A. Drijvende krachten. In: Van den Broek A, Van Campen C, De Haan J, Roeters A, Turkenburg M, Vermeij L, red. De toekomst tegemoet. Leren, werken, zorgen, samenleven en consumeren in het Nederland van later. Sociaal en Cultureel Rapport 2016. Den Haag: SCP, 2016: 17-48.

4. Van Campen C, Den Draak M, Ras M. Kwetsbaar alleen. Den Haag: SCP, 2011.

5. Putman L, Verbeek-Oudijk D, De Klerk M, Eggink E. Zorg en ondersteuning in Nederland: kerncijfers 2014. Den Haag: SCP, 2016.

6. Van Dam F, Daalhuizen F, De Groot C, Van Middelkoop M, Peeters P. Vergrijzing en ruimte; gevolgen voor de woningmarkt, vrijetijdsbesteding, mobiliteit en regionale economie. Den Haag: Planbureau voor de Leefomgeving, 2013.

7. Van Campen C, Kooiker S, De Boer A. Zorgen: Hoe gaan we als samenleving zorgen voor de groeiende groep ouderen. In: Van den Broek A, Van Campen C, De Haan J, Roeters A, Turkenburg M, Vermeij $L$, red. De toekomst tegemoet. Leren, werken, zorgen, samenleven en consumeren in het Nederland van later. Sociaal en Cultureel Rapport 2016. Den Haag: SCP, 2016: 108-142.

8. Josten E, De Boer A. Concurrentie tussen mantelzorg en betaald werk. Den Haag: SCP, 2015.

9. Henkens, K., Solinge, H. van, Damman, M. \& Dingemans, E. (2016), Langer doorwerken valt nog niet mee. Demos: bulletin over bevolking en samenleving 32 (2): 1-4.

10. Damman, M., \& Van Solinge, H. (2017) De combinatie van betaald en onbetaald werk in de jaren voor pensioen. Netspar Design Paper. Tilburg: Netspar.

11. Benders J. Liefde met voorbedachten rade. Rotterdam: Coolegem Media, 2016.

12. Billings J, Leichsenring K, Wagner L. Adressing Long-Term Care as a System. In: Leichsenring K, Billings J, Nies H, eds. Long-term Care in Europe. Improving Policy and Practice. Basingstoke, Palgrave MacMillan, 2013: 3-18.

13. Broese van Groenou MI. Informele zorg 3.0. Schuivende panelen en een krakend fundament. Amsterdam: Vrije Universiteit, 2012.

14. Morgan HM, Entwistle VA, Cribb A, Christmas S, Owens J, Skea ZC, Watt IS. We need to talk about purpose: a critical interpretive synthesis of health and social care professionals' approaches to self-management support for people with long-term conditions. Health Expectations, 2016, Doi:10.1111/hex12453.

15. Verhaeghe P. Identiteit. Amsterdam/Antwerpen: De Bezige Bij, 2012.

16. Gobet $P$, Emilsson T. Integration as 'Boundary Redifinition Process'. In: Leichsenring K, Billings $\mathrm{J}$, Nies H, eds. Long-term Care in Europe. Improving Policy and Practice. Basingstoke, Palgrave MacMillan, 2013: 118-139.

17. Beersma B. De kracht van coöperatie. Amsterdam: Vrije Universiteit, 2015.

18. Wolfe A. Whose keeper? Social science and moral obligation. Berkeley, CA: University of California Press, 2016.

19. Brandt M, Haberkern K, Szydlik M. Intergenerational help and care in Europe. Eur Soc Rev 2009; 25: 585-601.

20. Van den Broek MPB. Supporting ageing parents: A comparative analysis of upward intergenerational support. Rotterdam: Erasmus University, 2016.

21. Van der Pas S, Van Tilburg TG, Knipscheer CPM. Changes in contact and support within intergenerational relationships in the Netherlands: A cohort and time-sequential perspective. Adv Life Course Res 2007; 12: 243-274. 
22. Schenk N, Dykstra P, Maas I, Van Gaalen R. Older adults' networks and public care receipt: Do partners and adult children substitute for unskilled public care? Ageing Soc 2014; 34:17111729.

23. Saraceno C. Social inequalities in facing old-age dependency: A bi-generational perspective. J Eur Soc Policy 2010; 20:32-44.

24. Javornik J. Measuring state de-familialism: Contesting post-socialist exceptionalism. J Eur Soc Policy, 2014; 24:240-257.

25. Boïn A, Van Eeten M. Maatschappelijke veerkracht: Een nieuw ideaal doorgrond. In: Terugtreden is vooruitzien. Den Haag: RMO, 2013, 67-113.

26. De Klerk M, De Boer A, Plaisier I, Schyns P, Kooiker S. Informele hulp: wie doet er wat? Den Haag: SCP, 2015.

27. Jacobs MT, Aartsen MJ, Deeg DJH, Broese Van Groenou MI. Diversity in older adults' care networks: the added value of individual beliefs and social network proximity. J Gerontol Soc Sci, 2016. doi:10.1093/geronb/gbw012.

28. Huijnk W, Andriessen I. Integratie in zicht? De integratie van migranten in Nederland op acht terreinen nader bekeken. Den Haag: SCP, 2016.

29. Broese van Groenou MI, De Boer AH. Providing informal care in a changing society. Eur J Ageing 2016; 13:271-279.

30. Plaisier I, De Boer A, De Klerk M. Gevolgen van mantelzorgen. In: De Klerk M, De Boer A, Plaisier I, Schyns P, Kooiker S. Informele hulp: wie doet er wat? Den Haag: SCP, 2015: 89-110.

31. De Roos S A, de Boer AH, Bot SM. Well-being and Need for Support of Adolescents with a Chronically III Family Member. J Child Fam Stud 2016; 11. https://doi.org/10.1007/s10826016-0574-7.

32. Kennisplatform Integratie en samenleving. Mantelzorgers met een migratieachtergrond ondersteunen.Utrecht: Verwey-Jonker Instituut en Movisie, 2016.

33. Schans D, Komter A. Intergenerationele solidariteit en etnische diversiteit. Migrantenstudies, 2006; 22: 2-21.

34. Van der Heijde CM, Vonk P, Meijman FJ. (2015). Self-regulation for the promotion of student health. Traffic lights: the development of a tailored web-based instrument providing immediate personalized feedback. Health Psychol Beh Med 2015; 3:169-189. 